Indonesian Journal of
Mathematics and Natural Sciences Education
p-ISSN: 2721-172X e-ISSN: 2721-1746
Vol.1 No. 3 Th 2020; hal 193 -202
http://mass.iain-jember.ac.id

\title{
Penerapan Mind Mapping Berbantuan Google Classroom untuk Meningkatkan Hasil Belajar Siswa Kelas VII
}

\author{
Fika Rahmawati Sulistyaningrum ${ }^{1 *}$, Dyah Setyaningrum Winarni ${ }^{2}$, Indri Nurwahidah ${ }^{2}$ \\ 1 SMP Negeri 1 Pati, Jawa Tengah \\ 2 Universitas Ivet, Semarang, Jawa Tengah \\ *E-mail: fika19@yahoo.com
}

\begin{abstract}
Abstrak
Pola pengajaran yang konvensional di sekolah menjadikan siswa belum mampu menyerap konsep yang diajarkan, sehingga dibutuhkan model pembelajaran yang eksploratif dan menarik, seperti mind mapping. Pendekatan eksperimental pada kelas perlakuan dengan mind mapping dan kelas kontrol secara konvensional. Teknik pengumpulan data menggunakan instrumen tes untuk mengukur tingkat hasil belajar dan lembar observasi untuk mengukur penerapan mind mapping dalam proses pembelajaran. Hasilnya pembelajaran berjalan sesuai dengan prosedur pembelajaran. Hasil observasi pembelajaran terdapat 10 atau 36\% siswa dalam kriteria sangat baik, 11 atau 39\% dalam kriteria baik, 7 atau 25\% dalam kriteria cukup baik dan tidak ada yang masuk kriteria kurang baik. Sedang pada observasi penugasan terdapat 8 atau 29\% siswa dalam kriteria sangat baik, 13 atau 46\% siswa dalam kriteria baik, 7 atau 25\% siswa dalam kriteria cukup baik serta mengalami peningkatan hasil belajar dari nilai rata-rata kelas perlakuan dari 55 menjadi 86. Berdasarkan analisis korelasi t-tes tingkat signifikansi pengaruh pada level t-hitung 2,572 dan p-value 0,006. Pada analisis komparasi ttest tingkat signifikansinya berada pada level t-hitung bahwa t-hitung 3,563>t-tabel 2,052 dan p-value $0,001<$ p-tabel 0,001 dan berada pada derajat alpha 0,05. Pada tingkat efektifitas berdasar analisis n-gain berada pada level sedang atau cukup efektif pada taraf 0,57 .
\end{abstract}

Kata Kunci: Google classroom, peningkatan hasil belajar, mind mapping.

\section{PENDAHULUAN}

Kualitas pendidikan berkaitan erat dengan kualitas pembelajaran, karena kegiatan pembelajaran merupakan salah satu bentuk implementasi dari pendidikan di sekolah. Pembelajaran juga bisa diartikan sebagai sebuah proses kegiatan pelaksanaan kurikulum suatu lembaga pendidikan yang telah ditetapkan. Pemanfaatan sumber belajar di lingkungan sekitar mempunyai manfaat yang besar terutama dalam menumbuhkan pengalaman belajar siswa sehingga hasil belajar akan meningkat (Mujab, 2019; Winarni, 2017). Salah satu model pembelajaran mengeksplorasi daya pikir, kreatifitas, dan pemahaman siswa adalahmind mapping. Model pembelajaran ini merupakan proses memetakan pikiran untuk menghubungkan konsep-konsep permasalahan tertentu dari cabang-cabang sel saraf membentuk korelasi konsep, menuju 
pemahaman dan hasil yang dituangkan langsung di atas kertas dengan animasi yang disukai dan dimengerti (Daryanto \& Karim, 2017)

Susanto (2013) menyatakan bahwa science adalah usaha manusia dalam memahami alam semesta melalui pengamatan yang tepat pada sasaran serta menggunakan prosedur, dan dijelaskan dengan penalaran untuk mendapatkan kesimpulan.Itu artinya, dalam pembelajaran IPA guru harus mampu mendesain pembelajaran agar siswa memperoleh pengetahuan secara konkret tidak sekedar materi, tetapi lebih jauh dari itu siswa harus melaksanakan pengamatan secara langsung berdasarkan prosedur yang telah ditentukan (Hermawati, 2012). Jika pembelajaran tidak dinamis maka tujuan tersebut tidak bisa tercapai, sebab pembelajaran tidak hanya difokuskan untuk menghafal, namun siswa juga harus merasakan dan memahami secara detail materi dengan terlibat langsung dalam kegiatan pembelajaran dengan arahan guru sehingga siswa lebih aktif dan lebih mudah memahami materi.

Beberapa proses pembelajaraan yang dilakukan oleh guru, masih belum banyak melibatkan siswa untuk aktif dalam kegiatan pembelajaran. Sebagian siswa masih belum fokus saat menerima materi karena kompleksitas materi pelajaran IPA dan pola transformasi pembelajaran yang monoton. Melalui pengalaman belajar dapat merangsang rasa ingin tahu siswa, melatih siswa mengemukakan gagasan dan dapat membuat siswa lebih bertanggungjawab dalam proses pembelajaran serta melatih siswa memecahkan masalah (Asmani, 2010; Winarni, 2019; Nugraheni \&
Winarni, 2019). Itu artinya guru harus mengikutsertakan siswa dalam merancang desain pembelajaran agar pembelajaran dapat dilaksanakan secara seimbang dan dinamis. Pembelajaran aktif adalah dimana setiap individu memiliki tanggungjawab dan kesempatan yang sama dalam pembelajaran (Slavin, 2016).

Dari berbagai kondisi tersebut, maka dapat disimpulkan bahwa ada permasalahan pembelajaran dan dibutuhkan model pembelajaran yang lebih menarik dan eksploratif untuk mengatasi masalah tersebut dengan mengeksplorasi aspek pola pikir, penalaran, kreatifitas, imajinasi, spirit, pemahaman, kerjasama dan kesadaran belajar yang menyenangkan melalui model pembelajaran mind mapping dan merupakan cara termudah untuk menempatkan informasi ke dalam otak dan mengambil informasi ke luar otak, cara mencatat kreatif, efektif, secara harfiah memetakan pikiran-pikiran kita dengan sangat sederhana (Buzan, 2010). Dengan alat peraga atau alat bantu pembelajaran kemampuan siswa dalam memahami materi juga meningkat (Mahfud, 2019).

Menurut Wijayanti \& Listiyani (2019) model pembelajaran mind mapping efektif digunakan untuk meningkatkan hasil belajar, langkah eksplorasi pemahaman materi berbantuan beberapa informasi yang tercatat sebagai salah satu teknik mengingat yang mudah. Ukuran efektifitasnya tergambar prosesnya mulai dari mengumpulkan informasi dan mentransformasikan inti materi yang dibuat dalam bentuk kata kunci untuk memudahkan mengingat kembali informasi yang diperoleh. 
Oleh karena itu model pembelajaran mind mapping dapat dijadikan pilihan solusi untuk meningkatkan konsentrasi belajar siswa secara efektif, karena siswa tidak lagi dituntut untuk selalu mencatat namun lebih pada upaya merangsang siswa untuk mengetahui inti materi, dengan membuat peta materi sesuai pemikiran dan kreatifitasnya, sehingga berpotensi dapat meningkatkan hasil belajar khususnya pembelajaran IPA dengan karakteristiknya.

\section{METODE}

Pendekatan penelitian dalam kajian ini adalah penelitian lapangan berbasis pada penelitian eksperimental (experimental reseach) dengan jenis penelitian penelitian lapangan (field reseach) berbasis kuantitatif berkarakter quasi experimental design berbasis pada equivalent control group design. Instrumen penelitian ada lembar observasi pembelajaran dan lembar observasi penugasan untuk melihat dinamika proses pembelajaran, sedang untuk mengukur tingkat hasil belajar siswa menggunakan instrument tes yang sebelumnya diuji tingkat validasi, reliabilitas, indeks kesukaran dan daya bedanya dengan jumlah 20 butir soal pilihan ganda.

Analisis penelitian ini berbasis deskriptif kuantitatif mengenai penerapan mind mapping berbantuan google classroom untuk meningkatkan hasil belajar siswa kelas VII di SMP Negeri 1 Pati. Analisa uji normalitas menggunakan rumus liliefors dengan dua sampel, dan uji homogenitas berbasis pada test of homogenity of varience yang digunakan. Untuk mengukur tingkat pengaruh dan signifikansi per- lakuan menggunakan rumus t-test berbasis two sample equal variance dan untuk mengukur tingkat efektifitas perlakuan menggunakan $N$-gain versi Meltzer.

\section{HASIL DAN PEMBAHASAN}

Observasi pembelajaran dilakukan untuk melihat tingkat partisipasi siswa dalam mengikuti proses pembelajaran. Hal itu penting dilakukan apalagi proses pembelajaran tidak berbasis tatap muka namun menggunakan google classroom yang tentu memiliki perbedaan pada tingkat partisipasi dan keaktifan siswa. Dalam melakukan observasi pembelajaran digunakan lembar observasi berdasarkan tiga indikator utama, yaitu komunikatif dan interaktif, keterlibatan dan umpan balik siswa, dan ketekunan. Hasilnya terdapat 10 siswa yang mengikuti proses pembelajaran sangat baik, 11 siswa mengikuti proses pembelajaran secara baik, serta 7 siswa mengikuti proses pembelajaran cukup baik. Itu artinya, secara umum partisipasi siswa dalam proses pembelajaran dengan berbantuan google classroom berjalan lancar dengan tingkat partisipasi siswa yang baik.

Dalam melakukan observasi penugasan, ada 3 indikator yang digunakan, yaitu tingkat kejujuran dan orisinalitas, tingkat kedisiplinan dan tingkat kemandirian. Hasilnya terdapat 8 siswa yang mengikuti proses pembelajaran sangat baik, 13 siswa mengikuti proses pembelajaran secara baik, serta 7 siswa mengikuti proses pembelajaran cukup baik. Sehingga secara umum partisipasi siswa dalam proses penugasan memiliki tingkat partisipasi siswa yang baik. 
Indonesian Journal of Mathematics and Natural Science Education, 1 (3), 2020

Fika Rahmawati Sulistyaningrum, Dyah Setyaningrum Winarni, Indri Nurwahidah

Observasi hasil evaluasi pembelajaran perlu dilakukan untuk melihat gambaran umum proses pembelajaran yang telah dilaksanakan. Dari hasil evaluasi yang dilakukan pada tahap pretest dan posttest diperoleh hasil sebagai pada tabel 1 berikut:

Tabel 1. Jumlah Sampel

\begin{tabular}{clc}
\hline Tahap & \multicolumn{1}{c}{ Kelas } & Rata-rata \\
\hline$(1)$ & \multicolumn{1}{c}{$(2)$} & $(3)$ \\
\hline \multirow{2}{*}{ Pretest } & Perlakuan & 55 \\
& Kontrol & 69 \\
\hline \multirow{2}{*}{ Posttest } & Perlakuan & 86 \\
& Kontrol & 77 \\
\hline
\end{tabular}

Tabel 1 menunjukkan bahwa kelas perlakuan mengalami kenaikan dari nilai rata-rata pretest sebesar 55 pada nilai posttest menjadi 86 , sedang pada kelas kontrol dari nilai pretest 69 pada nilai posttest menjadi 77. Hasil belajar pada tahapan evaluasi posttest merupakan hasil belajar atau data yang diperoleh setelah perlakuan, sehingga dapat digunakan sebagai alat ukur yang akurat. Berdasarkan hasil analisis korelasi t-test diperoleh hasil sebagai ditunjukkan pada tabel 2 berikut.

Tabel 2. Hasil Analisis Korelasi T-Test

\begin{tabular}{lcc}
\hline & $\begin{array}{c}\text { Kelas } \\
\text { Perlakuan }\end{array}$ & $\begin{array}{c}\text { Kelas } \\
\text { Kontrol }\end{array}$ \\
\hline \multicolumn{1}{c}{$(1)$} & $(2)$ & $(3)$ \\
\hline $\begin{array}{l}\text { Rata-rata } \\
\text { Variasi }\end{array}$ & 86 & 77 \\
\hline $\begin{array}{l}\text { Jumlah yang } \\
\text { diamati }\end{array}$ & 28 & 289,729 \\
\hline $\begin{array}{l}\text { Varian yang } \\
\text { dikumpulkan }\end{array}$ & 182,507 \\
\hline $\begin{array}{l}\text { Rata } \\
\text { dihipotesiskan } \\
\text { berbeda }\end{array}$ & 0 \\
\hline $\begin{array}{l}\text { Derajat } \\
\text { kebebasan }\end{array}$ & \multicolumn{2}{c}{54} \\
\hline -hitung & 2,572 \\
\hline
\end{tabular}

\begin{tabular}{ccc}
\hline$(1)$ & $(2)$ & $(3)$ \\
\hline P-value & 0,006 \\
\hline T-tabel & 1,674 \\
\hline P-tabel & 0,013 \\
\hline
\end{tabular}

Tabel 2 menunjukkan bahwa ratarata nilai hasil belajar siswa kelas kontrol sebesar 77 dan kelas perlakuan sebesar 86, ada 183 varian yang dikumpulkan dan memiliki derajat kebebasan sebesar 54 serta hasil analisis korelasi t-hitung sebesar 2,572 serta p-value sebesar 0,006. Hasil ini kemudian diinterpretasikan dengan t-tabel sebesar 1,674 maupun $p$ table sebesar 0,013 dengan kriteria tolak $\mathrm{H}_{0}$ jika jika t-hitung > t-tabel dan p-value $<$ alpha 0,05. Berdasarkan hasil interpretasi kriteria tersebut menunjukkan bahwa terdapat pengaruh signifikan terhadap penerapan mind mapping berbantuan google classroom dalam meningkatkan hasil belajar siswa kelas VII SMP Negeri 1 Pati.

Pada analisis komparasi t-test juga diperoleh hasil yang signifikan. Hasil analisis korelasi t-test disajikan pada tablel 3 berikut.

Tabel 3. Hasil Analisis Komparasi T-test

\begin{tabular}{lcc}
\hline & $\begin{array}{c}\text { Kelas } \\
\text { Perlakuan }\end{array}$ & $\begin{array}{c}\text { Kelas } \\
\text { Kontrol }\end{array}$ \\
\hline \multicolumn{1}{c}{$(1)$} & $(2)$ & $(3)$ \\
\hline $\begin{array}{l}\text { Rata-rata } \\
\text { Variasi }\end{array}$ & 86 & 77 \\
\hline $\begin{array}{l}\text { Jumlah yang } \\
\text { diamati }\end{array}$ & 28,284 & 279,729 \\
\hline $\begin{array}{l}\text { Varian yang } \\
\text { dikumpulkan }\end{array}$ & 0,566 \\
\hline $\begin{array}{l}\text { Rata } \\
\text { dihipotesiskan } \\
\text { berbeda }\end{array}$ & 0 \\
\hline $\begin{array}{l}\text { Derajat } \\
\text { kebebasan }\end{array}$ & 0 \\
\hline -hitung & 27 \\
\hline P-value & \multicolumn{2}{c}{28} \\
\hline
\end{tabular}




\begin{tabular}{lll}
\hline \multicolumn{1}{c}{$(1)$} & $(2)$ & $(3)$ \\
\hline t-tabel & \multicolumn{3}{c}{2,052} \\
\hline$P$-tabel & \multicolumn{3}{c}{0,001} \\
\hline
\end{tabular}

Tabel 3 menunjukkan bahwa ratarata nilai hasil belajar siswa kelas kontrol sebesar 77 dan kelas perlakuan sebesar 86. Terdapat 0,566 korelasi personal dan memiliki derajat kebebasan sebesar 27 serta hasil analisis t-hitung sebesar 3,563 serta p-value sebesar 0,001. Hasil ini kemudian diinterpretasikan dengan $\mathrm{t}$ tabel sebesar 2,052 maupun p-tabel sebesar 0,001 dibawah derajat alpha 0,05.

Selain mengukur adanya pengaruh dan signifikansinya sebuah perlakuan mind mapping dalam pembelajaran, perlu juga mengukur tingkat efektifitas perlakuan. Dalam melakukan uji efektifitas digunakan rumus n-gain untuk melihat apakah penerapan mind mapping berbantuan google classroom pada materi interaksi makhluk hidup dengan lingkungannya pada siswa kelas VII SMP Negeri 1 Pati efektif atau justru sebaliknya tidak efektif dengan menggunakan rumus Meltzer. Berdasarkan data tabel dan kriteria tingkat efektifitas menunjukkan bahwa nilai $n$-gain sebesar 0,57 atau lebih besar dari 0,3 dan kurang dari 0,7 maka n-gain dikategorikan sedang, begitu pula menurut n-gain skor yang menyatakan bahwa n-gain berada pada level 56,77 dikategorikan cukup efektif. Artinya penerapan mind mapping berbantuan google classroom pada materi interaksi makhluk hidup dengan lingkungannya pada siswa kelas VII SMP Negeri 1 Pati dinyatakan pada katagori sedang dan cukup efektif.

Pada aspek perencanaan maka langkah identifikasi persoalan merupakan awal dalam menentukan proses lanjutan, termasuk menentukan model pembelajaran yang akan diterapkan (Wagiran, Sudji Munadi, \& Syukri F., 2014). Penerapan mind mapping adalah langkah yang tepat bila didasarkan pada adanya fakta bahwa hanya $30 \%$ siswa yang mampu mencapai KKM 75, pembelajaran dilaksanakan secara konvensional, serta tingkat partisipasi yang rendah. Hal itu, tidak semata-mata karena pola mind mapping yang eksploratif tetapi secara kreatif dan efektif mampu membantu siswa menerima, menyimpan, dan mengingat informasi yang diperoleh (Daryanto \& Karim 2017).

Pada aspek pelaksanaan penerapan mind mapping dalam sebuah pembelajaran, menggunakan bantuan google classroom adalah langkah praktis dan tepat yang digunakan untuk menjawab situasi dan kondisi di masa pandemi covid-19 ketika pemerintah menginstruksikan pembelajaran di rumah, sehingga penggunaan google classroom merupakan sarana untuk memudahkan proses pembelajaran. Selain itu, proses evaluasi dan penugasan yang semuanya diproses secara daring adalah indikator dari pembelajaran yang komprehensif menunjukan bahwa pembelajaran sangat mempertimbangkan aspek, interaksi yang memiliki tujuan, prosedur yang jelas dan sistematis, memiliki kekhasan serta merangsang keaktifan siswa (Sunhaji, 2011)

Penggunaan mind mapping berbantuan google classroom akan efektif bila seluruh proses dan tahapan dilaksanakan dengan baik, karena model pembelajaran mind mapping menekankan pada proses akselerasi pemetaan pemikiran dan pemanfaatan seluruh potensi 
Indonesian Journal of Mathematics and Natural Science Education, 1 (3), 2020

Fika Rabmawati Sulistyaningrum, Dyah Setyaningrum Winarni, Indri Nurwabidah

otak melalui citra visual (Syam \& Ramlah, 2016).

Hasil observasi pembelajaran (tabel 4) diketahui terdapat 10 atau $36 \%$ siswa dalam kriteria sangat baik, 11 atau 39\% dalam kriteria baik, 7 atau $25 \%$ dalam kriteria cukup baik dan tidak ada yang masuk kriteria kurang baik. Sedang pada observasi penugasan terdapat 8 atau $29 \%$ siswa dalam kriteria sangat baik, 13 atau $46 \%$ siswa dalam kriteria baik, 7 atau $25 \%$ siswa dalam kriteria cukup baik, dan tidak ada siswa yang masuk katagori kurang baik.

Tabel 4. Persentase Observasi

Pembelajaran dan Penugasan

\begin{tabular}{ccccc}
$\begin{array}{c}\text { Kri- } \\
\text { teria }\end{array}$ & $\begin{array}{c}\text { Obser- } \\
\text { vasi } \\
\text { Pembe- } \\
\text { lajaran }\end{array}$ & $\begin{array}{c}\text { Perse } \\
\text { ntase }\end{array}$ & $\begin{array}{c}\text { Obser- } \\
\text { vasi } \\
\text { Pembe- } \\
\text { lajaran }\end{array}$ & $\begin{array}{c}\text { Perse } \\
\text { ntase }\end{array}$ \\
\hline$(1)$ & $(2)$ & $(3)$ & $(4)$ & $(5)$ \\
\hline Tinggi & 10 & 36 & 8 & 29 \\
Sedang & 11 & 39 & 13 & 46 \\
Rendah & 7 & 25 & 7 & 25 \\
\hline
\end{tabular}

Perbedaan hasil observasi dari dua instrumen di atas menunjukkan adanya fakta bahwa proses pembelajaran yang sangat baik belum tentu menghasilkan hasil penugasan yang sangat baik pula, tetapi pada sebagian besar siswa menunjukkan bahwa hasil observasi pembelajaran memiliki pengaruh yang sama atau berbanding lurus dengan hasil observasi penugasan.

Hasil pengumpulan data didapatkan dari pretest dan posttest sebagai data utama. Peneliti juga melakukan pengamatan yang bertujuan untuk menemukan gambaran dari proses pembelajaran yang dilakukan (Abdillah, 2012), sekaligus sebagai indikasi sikap dan respon siswa terhadap perlakuan. Hasil pengamatan menunjukan bahwa seluruh kelas telah memenuhi tahap dan prosedur pembelajaran yang ditentukan sesuai dengan tahapan-tahapan pembelajaran yang telah dirumuskan dalam Rencana Pelaksanaan Pembelajaran (RPP) secara sistematis. Desain pembelajaran yang baik adalah ketika proses pembelajaran di kelas dilaksanakan secara sistematis (Solihatin, 2018).

Tahapan pembelajaran yang dilakukan pada kelas perlakuan mind mapping yakni penjelasan materi, tugas kelompok, pengamatan, identifikasi dan pemetaan menggunakan pendekatan untuk menentukan tema dan sub tema mapping, penugasan dan evaluasi. Begitu pula kelas kontrol yang dilaksanakan secara konvensional yakni penjelasan materi, diskusi kelompok, penugasan dan evaluasi.

Pada tahap awal peneliti melakukan pretestpada kedua kelas baik kelas perlakuan maupun kelas kontrol. Perbandingan hasil belajar pada tahap evaluasi melalui pretest dari kelas kontrol maupun kelas perlakuan. Pada nilai pretest pada kelas kontrol memiliki nilai lebih tinggi dengan rata-rata sebesar 69 dan standar deviasi 21,06 sedangkan nilai pretest kelas perlakuan mind mapping memiliki nilai rata-rata 55 dan standar deviasi sebesar 15,36. Artinya kelas kontrol memiliki nilai yang lebih tinggi dari kelas perlakuan dan persebaran nilai yang lebih merata dibandingkan dengan kelas perlakuan.

Langkah-langkah evaluasi dilakukan dengan menggunakan instrumen tes yang sama dan telah melalui serangkaian pengujian yakni uji tingkat validasi, reliabilitas, indeks kesukaran dan daya beda sebanyak 20 butir soal dengan format soal pilihan ganda. Pada nilai posttest, kelas kontrol memiliki nilai rata- 
rata sebesar 77 dan standar deviasi 9,23, sedangkan nilai posttest kelas perlakuan mind mapping memiliki nilai rata-rata 86 dan standar deviasi sebesar 16,73. Artinya kelas perlakuan mind mapping memiliki peningkatan nilai sebesar 86 dan persebaran nilai yang lebih merata dibandingkan dengan kelas kontrol. Hasil tersebut kemudian diperbandingkan untuk melihat peningkatan hasil belajar antara kelas kontrol dan perlakuan, data tersebut disajikan dalam tabel 5 berikut.

Tabel 5. Perbandingan Hasil Belajar

\begin{tabular}{ccccc}
\multicolumn{3}{c}{ Pretest-Posttest } \\
\hline Aspek & \multicolumn{2}{c}{ Pretest } & \multicolumn{2}{c}{ Posttest } \\
\cline { 2 - 5 } Analisa & $\begin{array}{c}\text { Kelas } \\
\text { Kontrol }\end{array}$ & $\begin{array}{c}\text { Kelas } \\
\text { Perlakuan }\end{array}$ & $\begin{array}{c}\text { Kelas } \\
\text { Kontrol }\end{array}$ & $\begin{array}{c}\text { Kelas } \\
\text { Perlakuan }\end{array}$ \\
\hline$(1)$ & $(2)$ & $(3)$ & $(4)$ & $(5)$ \\
\hline Rata-rata & 69 & 55 & 77 & 86 \\
Skor & 95 & 95 & 100 & 100 \\
$\begin{array}{c}\text { Tertinggi } \\
\text { Skor }\end{array}$ & 20 & 40 & 70 & 50 \\
$\begin{array}{c}\text { Terendah } \\
\text { Median }\end{array}$ & 50 & 65 & 85 & 75 \\
Modus & 40 & 65 & 95 & 75 \\
$\begin{array}{c}\text { Standar } \\
\text { Deviasi } \\
\text { Jumlah }\end{array}$ & 21,06 & 15,36 & 9,23 & 16,73 \\
Siswa & 28 & 28 & 28 & 28 \\
\hline
\end{tabular}

Pada tabel 5 menunjukkan terdapat peningkatan hasil pada tahap posttest baik pada kelas kontrol maupun kelas perlakuan di mana pada kelas kontrol memiliki nilai rata-rata 77 setelah sebelumnya pada tahap pretest memiliki nilai rata-rata 69 dengan standar deviasi dari 9,23 pada posttest dan 21,06 pada tahap pretest. Sedangkan kelas perlakuan mind mapping pada tahap posttest memiliki nilai rata-rata 86 setelah sebelumnya pada tahap pretest memiliki nilai rata-rata 55 dengan standar deviasi 16,73 pada tahap posttest dan 15,36 pada tahap pretest. Artinya kelas perlakuan mind mapping lebih unggul dari aspek penilaian sekaligus pada aspek persebaran nilai.

Pada aspek peningkatan hasil belajar siswa kelas VII SMP Negeri 1 Pati menunjukkan bahwa model pembelajaran mind mapping mampu meningkatkan hasil belajar siswa secara signifikan. Hal itu berdasarkan hasil hitung korelasi t-test menunjukkan bahwa t-hitung 2,572 > t-tabel 1,674 dan p-value 0,006 < p-tabel 0,013 dan derajat alpha 0,05. Pada hasil hitung komparasi t-test menunjukkan bahwa t-hitung 3,563 $>$ t-tabel 2,052 dan p-value 0,001 < p-tabel 0,001 dan berada pada derajat alpha 0,05.

Dengan demikian hasil interpretasi kriteria tersebut menunjukkan bahwa terdapat pengaruh peningkatan hasil belajar dalam penerapan mind mapping berbantuan google classroom siswa kelas VII SMP Negeri 1 Pati. Hasil dari analisis tingkat efektifitas n-gain menunjukkan bahwa nilai n-gain hitung sebesar 0,57 atau lebih besar dari 0,3 dan kurang dari 0,7 . Itu artinya tingkat efektifitas penerapan mind mapping berada kriteria ke dua atau pada level sedang dan nilai $n$ gain skor berada pada level 56,59 artinya pada level 56,75 sehingga penerapan mind mapping berbantuan google classroom pada materi interaksi makhluk hidup dengan lingkungannya pada siswa kelas VII SMP Negeri 1 Pati dinyatakan pada katagori cukup efektif.

Dengan demikian, berdasarkan hasil analisis hitung menggunakan rumus dan n-gain diperoleh hasil bahwa baik nilai n-gain maupun n-gain score berada pada level sedang atau cukup efektif. Hasil ini juga menunjukkan bahwa mind mapping merupakan salah 
Indonesian Journal of Mathematics and Natural Science Education, 1 (3), 2020

Fika Rabmawati Sulistyaningrum, Dyah Setyaningrum Winarni, Indri Nurwabidah

satu model pembelajaran yang terbukti cukup efektif karena berorientasi pada kinerja otak secara bersamaan dan seimbang (Zulyani, et al, 2014).

Berdasarkan dari hasil hitung 2 rumus analisis baik $t$-test maupun $n$-gain menunjukkan adanya peningkatan hasil belajar secara signifikan sekaligus menunjukkan tingkat efektifitas pembelajaran yang cukup efektif pada proses pembelajaran, sehingga pembelajaran dapat dinyatakan berhasil karena peningkatan hasil belajar secara signifikan dan tingkat efektifitas yang sedang dan cukup efektif. Pembelajaran yang efektif diharapkan mampu meningkatkan kemampuan analisis dan motivasi siswa sehingga hasil belajar siswa juga meningkat (Winarni, 2020). Peningkatan hasil belajar bermakna bahwa siswa memahami konsep yang dibelajarkan oleh guru.

\section{SIMPULAN}

Hasil penelitian ini dapat disimpulkan bahwa penerapan mind mapping berbantuan google classroom siswa kelas VII SMP Negeri 1 Pati menunjukkan pada level sedang atau cukup efektif yang mendukung ketercapaian pembelajaran dengan hasil belajar yang meningkat dan perlu penguatan pemahaman siswa terhadap materi sehingga siswa mampu menentukan tema besar dan sub-tema secara tepat dan efektif.

\section{DAFTAR PUSTAKA}

Abdillah, R. (2012). Pembelajaran Berbasis Pemanfaatan Sumber Belajar. Jurnal Ilmiah Didaktika. Vol. XII. No. 2: 216-231.
Asmani, J.M. (2010). Tips efektif aplikasi ktsp di sekolah. Yogyakarta: Bintang Press.

Buzan, T. (2010). Mind map untuk meningkatkan kreativitas. Jakarta: Gramedia Pustaka Utama.

Balai Penelitian dan Pengembangan. (2013). Pembelajaran dengan pendekatan scientific. Jakarta: Kemendikbud.

Daryanto \& Karim. (2017). Pembelajaran abad 21. Yogyakarta: Gava Media.

Hermawati, N.W.M. (2012). Pengaruh Model Pembelajaran Inkuiri Terhadap Penguasaan Konsep dan Sikap Ilmiah Siswa SMA Ditinjau dari Minat Belajar Siswa. Jurnal Pendidikan dan Pembelajaran IPA Indonesia. 2 (2): 1-30.

Mahfud, \& Mahfud, N. (2019). Peningkatan Hasil Belajar Siswa dengan Menggunakan Alat Peraga IPA Kelas III MI Islamiyah Kudus. Indonesian Journal of Mathematics and Natural Science Education. 1 (1): 27-36.

Mujab, S., Diah N., \& Dyah S.W. (2019). Penerapan Pembelajaran Bioenterpreneurship Pada Materi Bioteknologi Fermentasi Kefir Untuk Meningkatkan Motivasi Belajar Siswa. Indonesian Journal of Natural Science Education (IJNSE). 2 (2): 227-231.

Nugraheni, D., \& Dyah S.W. (2019). Peningkatan Keterampilan Proses dan Hasil Belajar Mahasiswa melalui Pembelajaran Science Teacherpreneurship. Jurnal Ilmiah 
Pendidikan IPA (Natural). 6 (2): 7885.

Solihatin, E. (2012). Strategi pembelajaran coorperative. Jakarta: Damai Press.

Subana, M. \& Sudrajat. (2011). Dasardasar penelitian ilmiah. Bandung: Pustaka Setia.

Slavin, R.E. (2012). Cooperative learning: teori, risetdan praktik. Bandung: Nusa Media.

Sunhaji. (2011). Strategi pembelajaran: konsep dasar, metode dan aplikasi dalam proses belajar mengajar. Yogyakarta: Grafindo Litera Media.

Susanto, H., Rinaldi, A., \& Novalia. (2015). Analisis Validitas Relibilitas Tingkat Kesukaran dan Daya Beda pada Butir Soal Ujian Akhir Semester Ganjil Mata Pelajaran Matematika Kelas XII IPS di SMA Negeri 12 Bandar Lampung TahunAjaran 2014/2015. Al-Jabar: Jurnal Pendidikan Matematika. 6 (2): 203-217

Syam, N., \& Ramlah. (2015). Penerapan Model Pembelajaran Mind Mapping dalam Meningkatkan Hasil Belajar pada Mata Pelajaran Ilmu Pengetahuan Sosial Siswa Kelas IV SDN 54 Kota Parepare. Jurnal Publikasi Pendidikan. 5 (3): 2088-2092.

Wagiran, Munadi, S., \& Fathudin, S. (2014). Pengembangan Model Penguatan Soft Skills dalam Mewujudkan Calon Guru Kejuruan Profesional Berkarakter. Jurnal Kependidikan. 44 (1): 92-102.
Wijayanti, A., Listiyani, \& Rochmawati, L. (2019). Meningkatkan Motivasi Mahasiswa Calon Guru IPA Melalui Cooperative Learning Tipe Take and Give Berbantuan Mind Mapping. JIPVA : Jurnal Pendidikan IPA Veteran. 3 (2): 2598-5876.

Winarni, D.S. (2017). Analisis Kesulitan Guru PAUD dalam Membelajarkan IPA pada Anak Usia Dini. Edusains: Jurnal Pendidikan Sains dan Matematika. 5 (1): 12-22.

Winarni, D.S. (2019). Pembelajaran dengan Teknik Pemaparan Sesame untuk Meningkatkan Soft Skills Mahasiswa. Edusains: Jurnal Pendidikan Sains dan Matematika. 7 (2): 44-51.

Winarni, D.S. (2020). Effectiveness of Virtual Anatomy System (VAS) Media to Improve Students' Analysis Ability Towards Reproduction System Materials. Indonesian Journal of Science and Education. 4 (1): 43-47.

Zulyani, R., Sari, S.A., \& Pontas, K. (2014). Hubungan Hasil Pembuatan Mind Mapping dengan Hasil Belajar pada Materi Kromatografi Kertas Di Jurusan Pendidikan Kimia IAIN Ar-Raniry. Jurnal Pendidikan Sains Indonesia. 2 (1): $47-53$

\section{PROFIL SINGKAT}

Fika Rahmawati Sulistyaningrum adalah guru IPA di SMP Negeri 1 Pati sejak 2007 dan aktif sampai sekarang merupakan alumni Universitas Diponegoro. 
Indonesian Journal of Mathematics and Natural Science Education, 1 (3), 2020

Fika Rabmawati Sulistyaningrum, Dyah Setyaningrum Winarni, Indri Nurwabidah

Dyah Setyaningrum Winarni merupakan dosen Pendidikan IPA di Universitas Ivet sejak 2016. Bidang keahliannya dalam Pendidikan Biologi, alumni Pendidikan IPA Universitas Negeri Semarang. Aktif dalam kegiatan penelitian bidang IPA dengan konsentrasi Biologi.

Indri Nurwahidah menjadi dosen di Universitas Ivet sejak 2016. Dengan kehalian bidang Pendidikan Fisika alumni Universitas Negeri Semarang. 